\title{
Democratising welfare
}

Finally, we turn our attention to what I call welfare democracy and, in the account that follows, I argue that this is a means of bringing together the principles of attention and distributive justice. In Chapter 6, we saw that the principles overlap without either being reducible to the other and, although these ideas will no doubt continue to be discussed by social theorists in years to come, there is a need to debate the possible policy implications of these principles, a need that is generally being neglected. Our aim in this chapter is not to establish the full range of these implications, since they span a much wider intellectual terrain than we are required to explore in this book. However, I do want to examine one aspect of that terrain: welfare reform. I will suggest that dialogical institutions and systems are the best means of achieving recognition, care and distributive justice while allowing the relevant tensions to be aired and discussed creatively, albeit in a way that never permits a final resolution. This means engaging with ideas of deliberative (or discursive) democracy and relating them to the field of social policy.

We begin with social citizenship and I will argue that conservatives were able to grab the initiative partly because social rights were detached from the need to further advance the democratic project. We then contrast aggregative democracy and deliberative democracy and I observe that a reconciliation of 'procedure' and 'pluralism' is even more crucial for the latter than the former. We then apply these arguments to social policy and I sketch a theoretical outline of a welfare democracy. Essentially, the democratisation of welfare must represent a political alternative to conservatism and we spend much of the chapter analysing the obstacles in the path of that alternative and how they might be surmounted. This leads into a discussion of social movements and why such movements might offer an alternative to conservatism if they can build new constituencies with social democratic parties. We finish by exploring associative democ- 
racy and concluding that association and deliberation are invaluable aspects of a new, progressive politics.

\section{The political deficits of social citizenship ${ }^{1}$}

Traditional forms of state welfare have been on the defensive since the 1970s, often by those opposed to, or critical of, universalism. The Right are opposed to the practice of state universalism, since they believe that universal services and benefits waste resources by being inefficiently targeted upon low-income households and by encouraging dependency. However, while this requires the transformation of state welfare into a selectivist and punitive system, the principle of universalism (to which they are not necessarily opposed) can be embodied in market relations, because markets treat everyone the same. Conversely, some on the Left have been critical of universalism in theory, but not necessarily in practice. They allege that universalism has either neglected or even suppressed a spectrum of social identities, categorical boundaries and cultural boundaries by implicitly treating white, heterosexual, able-bodied men as the normative ideal (Butler, 1990). This does not mean that universal services should be abandoned, merely that universality should be much more sensitive to the particular differences of diverse social groups (Thompson and Hoggett, 1996).

For some this assault adds up to the same thing: the abandonment of class-based social justice (Taylor-Gooby, 1994, 1997). But my view is that such traditionalism is too defensive, too quick to confuse the Right's rejection of state practice with the (cultural) Left's suspicion of crude universalism (Fitzpatrick, 1996). For, whereas suspicion towards materialist and distributive paradigms undoubtedly increased in the 1970s and 1980s, often under cover of postmodernist and post-structuralist critiques, the 1990s brought a greater spirit of rapprochement that may yet translate into a new form of radical politics. Therefore there has emerged a 'postuniversalism' that may supply the resources capable of rebuilding welfare systems on a ground that is more immune to attacks from the Right than traditional state-centred collectivism. This is because what postuniversalism offers is a means of repairing the democratic deficit that assisted the crisis of universalism in the first place.

For post-universalism, the essential problem lies in the tendency to regard liberal democracy as the final stage of modernity, rather than as a key but transitional stage in the democratisation of society. This assumption is latent within Marshall's famous account, where social rights are thought to complete the journey towards full citizenship such that the conjunction of market, democratic and welfarist institutions represents 
the summit of the modern project (Marshall and Bottomore, 1992). Whatever the specifics of Marshall's theory, he articulates the confidence of post-war social democrats that laissez-faire capitalism had been routed once and for all, a confidence that had been shattered by the mid-1980s and from which social democracy is still trying to recover. Of course, the idea that liberal democracy is not the end of modernity was widely shared on the Left and tracks back as far as Marx in the 1840s. Unfortunately, with the discrediting of political radicalism (whether your baseline is 1956, 1968, 1979 or 1989) two options have dominated; some have hung on to the dream of modernity by settling for liberal democracy, others have wanted to go beyond liberal democracy by transcending modernity also, hence the fashion for postmodernism and the cultural turn. A third option - of regarding the radicalisation of the democratic project as a project of modernity - is still struggling for intellectual space.

But if this third post-universalist option is worth exploring, then what does it imply for democracy and for the greatest achievement of social democracy, the welfare state?

To some extent the Right were correct to identify the failure of state welfare to empower the powerless. For a variety of reasons (not all of them bad) post-war governments settled into a mean of complacency, where a Man-from-the-Ministry-knows-best attitude prevailed and when paternalist collectivism seemed to succeed more often than it failed. Consequently, there was usually an administrative gulf between those who produced and those who used welfare services, with the latter often feeling that they did not really own the welfare state. The enduring ambiguity of the traditional welfare state is that it both empowered and disempowered, laying in the social soil only shallow roots that would struggle to replenish the conditions of its own continuation. ${ }^{2}$ Unfortunately, the Right were wrong to imagine that disempowerment was due to the association of 'rights' with 'social' as, in truth, social rights carried this ambiguity because they were detached from the category of the political. Social rights were vulnerable, not because they were too radical, but because they were not radical enough and failed to carry forward the democratisation of the economy and society. So, rather than seek to replace welfare clients with welfare citizens, the Right sought to redefine us as welfare consumers: the lack of empowerment was interpreted as a lack of market choice (exit) rather than a lack of democratic input (voice).

In short, social democrats like Marshall had taken one version of citizenship - where civil, political and social rights are semi-detached from one another in a 'hyphenated' society - and interpreted it as the final version. In retrospect, it was depressingly easy for conservatives to unpick this conception and adapt welfare institutions to an ethic within which social rights and entitlements play a diminishing role. This ethic of market 
individualism, authoritarian populism and coercive obligations has in turn infiltrated the social democratic vocabulary, though especially that of the NSD, even as the high-water mark of conservatism has passed. Social citizenship therefore continues to compel, but it currently emptied of a determinate content, whether conservative or anything which is recognisably social democratic.

So we have experienced three stages of post-war social policy. ${ }^{3}$ First, the one-size-fits-all assumptions of state collectivism offered some measure of security to individuals defined as worker-clients, but little actual control over welfare institutions. Second, the Right interpreted empowerment in terms of market consumerism and social duties, ignoring democracy altogether. Third, the NSD has not broken away from the Right's hegemony in its expectation that people should be socially active (in employment), but politically passive. We are not condemned to this third stage, though. If the democratic deficit left the social dimensions of citizenship vulnerable to the simplistic analyses of the Right, repairing that deficit may make social rights less vulnerable to any further assaults from the Right in the future. However, this would seem to demand more than the simple recreation of state-centred collectivism, as traditionalists imagine, since it was collectivist paternalism which helped create the deficit in the first place. ${ }^{4}$

\section{Imagining deliberative democracy}

For post-universalists, the problem is not democracy per se, but aggregative democracy. Aggregative democracy treats citizens largely as voters whose preferences are already given and merely need to be aggregated through the mechanisms of electoral representation. The problem with aggregative democracy is that, by treating citizens as little more than voters, it both distances the state from civil society and allows the former too great a control over the latter. Aggregative democracy therefore engenders a distorted public sphere: one that is too attenuated to be popularly accountable and yet too congested upon political parties to replicate the transparent agora of ancient democracy. For these and other reasons, many now call for deliberative reforms that stress voice as well as exit and vote (Dryzek, 1990, 1996, 2000; Phillips, 1995; Gutmann and Thompson, 1996; Benhabib, 1996; Elster, 1998; Cooke, 2000; Warren, 2002). Whereas aggregative democracy merely counts preferences, deliberative democracy enables preferences and beliefs to be transformed through discursive interaction with others; whereas the former is instrumentalist, the latter takes account of ends as well as means; and whereas the former is representative, the latter introduces participatory elements that seem more 
practical and realistic than calls for direct democracy. Of course, the distinction between aggregative and deliberative democracy is not hard and fast and, unless we were to aim at a thoroughgoing participative democracy (an option that seems too remote), the representative mechanisms of aggregation would have to be incorporated within a deliberative context, if for no other reason than that a deliberative democracy cannot emerge sui generis. However, many insist that deliberative democracy would represent a considerable advance on aggregative representation, with demands for citizens' juries and parliaments (Smith and Wales, 2000), policy panels, frequent referenda and electronic public spaces (Tsagarousianou et al., 1998) of increasing interest.

But if this is how aggregative and deliberative democracy basically contrast, then why has the latter recently become so popular among social theorists? What is the problem to which deliberative democracy is the potential solution? ${ }^{5}$

We find ourselves in a curious situation. Never in human history has democracy been so popular, and yet never has it so clearly failed to engage and animate the electorates who benefit from it. Apathy has infected the polity across a number of countries (though by no means all), indicated most obviously by low voter turnouts, as government elites manage from distances ever more removed from the spaces that their managerial actions affect. Occasionally something happens to stir this apathy away and for a time the blood of politics flows more rapidly through democracy's veins, yet these have largely been temporary moments that have not yet revived the social body in full. What political energy there is has tended to be re-active, and the re-awakening of the European Far Right in recent years has only compounded this. Whatever its abstract popularity as an idea then, democratic practices and institutions have begun to atrophy.

In this respect, society resembles human psychology in that both subsist upon the sound of different voices. But whenever a consciousness merely talks to itself in different voices, all that emerges are replicated echoes of what is essentially the same sound. What follows is isolation, breakdown and a drift into silence. Contrast this with the situation where genuinely different voices talk to each other in a cacophony of sound, where consciousness becomes another in a conversation of others. Here, consciousness no longer feeds merely on itself, but has a wider world on which to nourish. The job of democracy is to conduct this cacophony, to make sense of the noise which it encourages, to maintain the health of unity and difference. Unity searches for difference because it cannot do anything else; it has nowhere else to go. But the relationship between unity and difference may be either well or ill. Unity may seek a new context or it may set out to blame difference for itself; it may embrace 
itself within a network of differences or try to uncritically assimilate difference within itself; it may become what is affirmable or simply try to affirm what already is; it may exteriorise itself or else make everything into an interior that has no outside with which to converse. Democracy is therefore an ordered yet chaotic conversation in which sameness comes to consciousness of itself through the voices of difference.

It is here that existing democracies are failing. It is not as if there is not enough sound; indeed, the 'noise from below', from the shadows and corners of civil society, has rarely been louder. Yet this noise is not connecting with the body politic for two reasons. First, because although the noise can sound political, it searches for a new politics that traditional systems and institutions have little desire to hear; second, because the noise is often not being given a political voice at all. The fault is therefore similarly twofold. Those elites who will not listen for the new sounds are equally culpable with those within civil society who reject the political, whether old or new. The future of democracy therefore depends upon repairing this connection, upon transforming the noises from below into institutions capable of hearing them. This is the central rationale for deliberative democracy: to repair the hearing of political institutions by opening them to the discursive sounds of civil society. (And increasing social capital is not enough (Putnam, 2000). Democracy requires social capital, but not a social capital whose purpose is simply to plug the communal gaps of market individualism. For although we must trust those with whom we converse, we must be as busy talking to those we would not want to go bowling with as those with whom we would.) Yet here is the dilemma.

Democracy depends upon both procedures and pluralism. By 'procedures' I mean the constitutions, laws, conventions, rules and systems through which democracy runs, the machinery of politics; by 'pluralism' I mean the clamour, spontaneities, reflectiveness and dreams that provide meaning, the messiness of social life, of the lifeworld. If there is too much emphasis upon procedure, then pluralism is stifled, has no air to breathe; if there is too much emphasis upon pluralism, then procedures are potentially destabilised as chaos overwhelms the borders within which it must be contained to be socially valuable. Achieving this balance is the permanent problem of democracy. Yet the problem is particularly acute in the case of deliberative democracy precisely because the purpose of deliberation is to break procedures open to the discursive noise that they have been keeping at bay. How then is this to be done? How can democracy deliberate while still being recognisably democratic?

As Borjeson (2002) pointed out in response to an earlier version of these arguments (Fitzpatrick, 2002b), there is no easy solution, but some cause for optimism. After all, because the trajectory of deliberative democracy 
is not to replace its aggregative predecessors but to revitalise them, the former has much to learn from the latter, specifically, the ways in which pluralism can itself be an aspect of procedural mechanisms. For the most part, pluralism is written into procedure in the form of elections and written constitutions that allow for their own reformation under particular, carefully controlled circumstances. Moreover, there are examples from the history of aggregative democracy that inspire deliberative reform by anticipating it. Think of the repeal of prohibition in the USA, for instance, when a more mature approach to civil society was forced upon the governing elite by the noisy, ridiculing non-compliance of civil society itself (even if this non-compliance had its darker side in the form of organised crime). Therefore, it is possible to envisage pluralism-sensitive procedures that build upon the systems already available to us. But whereas aggregative democracy treats elections merely as a vote for the take-it-or-leave-it packages of parties, deliberative elections would need to intervene in the agenda-setting process much earlier than our top-heavy political parties currently allow. In short, we need to envisage a much more creative interface between parliamentary and non-parliamentary forms of politics and I will have more to say about this later.

Beforehand, let me say something briefly about one sphere that will be absolutely crucial if this balancing of procedures with pluralism is to be effective and if the deliberative citizen is to emerge. ${ }^{6}$

The links between substantive democracy, active citizenship and effective education have long been noted (e.g. Enslin et al., 2001). To this mixture, Gutmann has added social justice because beyond a certain threshold (Rawlsian perhaps) inequality renders the practices of democracy, citizenship and education increasingly meaningless. Therefore: 'We must rely on our imperfect democratic politics to generate demands for better living and working conditions and more democratic political institutions. What conceivable change in our economic or political institutions is likely to generate these demands more effectively in the future than improving the education of children today?' (Gutmann, 1987: 286). As you will see below, I concur with this analysis, even if I think that Gutmann's prescription is fairly complacent. The problem is that education is itself a site of political contestation, as conservatives have spent over 30 years demonstrating in their repeated assaults on trendy liberal teachers, methods and theories. Therefore, we cannot improve the education of children without understanding the democratic and social objectives that we want an educational system to serve and since those objectives will always be subject to struggle, so will our ideas as to what educational improvement actually involves.

In the UK the introduction of 'Citizenship' into the National Curriculum (as of September 2002) is one potential counter-assault to the Right 
(Crick, 2000: Chs 7-9; Pring, 2001; Schuller, 2001) since it makes room for the kind of reflective discussions that chalk-and-talk conservatives dislike. The problem is that the 'light touch' it applies (to avoid accusations that lessons could represent indoctrination into one version of citizenship) may still not do enough to encourage in pupils the kind of critical faculties that are anathema to the capitalist need for energetic, moderately intelligent and skilled workers.

In a sense, what I have in mind here is a version of Macintyre's (1982: 219) statement that, ' . . . the good life for man is the life spent in seeking for the good life for man, and the virtues necessary for the seeking are those which will enable us to understand what more and what else the good life for man is'. For what Macintyre envisages here is an 'education in the virtues', i.e. in the ability to recognise, value and enjoy the 'practices', i.e. the internal, non-instrumental qualities of activities. This kind of education therefore pulls away from prevailing conceptions where citizenship implies wage earning and so education shrinks towards the sphere of employment. But Macintyre's is ultimately a strong communitarianism for which the nature of virtue resides within tradition and within the accepted canons. It treats the virtues as given and so its ethics is conservative and hierarchical, out of step with the modern, reflexive self.

Yet Macintyre's injunction to search for the good life is compelling and leads us towards a deliberative idea of welfare. This would be grounded in received notions of well-being (the realisation of socially-relative basic needs), but would also go further. For deliberative welfare is ultimately about a collective, democratic quest whose value resides in the fact that the expedition is endless. At its highest level, well-being arrives through the search for well-being, a search that is rooted in a democratic deliberation that does not seek its end. Thus welfare is given an Aristotelian spin that we can call self-referential well-being. Well-being is not a thing, a condition, nor even a set of fulfilled needs, but a performative process of becoming. As noted in Chapter 2, we improve the sum of social welfare, not by promoting a single version of the good, but by expanding individuals' capacities to improve the available range of meaningful goods. Therefore, a welfare democracy is that which would give institutional form to this notion of self-referential well-being. A welfare democracy requires the deliberative citizens that only it itself can properly educate. Not 'education for employment' nor 'education in the virtues' but 'education for discourse', for the arts of speaking and listening that are at the heart of democratic interaction. Here we find the deliberative citizen capable of following procedures, without allowing them to ossify into ineluctable authorities, and of playing with plural discourses, without allowing them to overwhelm. 
Education for discourse therefore implies that social time (time spent by autonomous citizens in sociable and justice-enhancing activities) can only be fully emancipated by citizens who are capable of sharing it. Freed time loses meaning without self-referential well-being, and self-referential well-being requires the freeing up of social time so that we are no longer squeezed between the reinforcing grips of employment and consumption. And for time to be emancipated as social time, employment activity must not only be reduced, but new civic spaces of discursive interaction opened up. And it is within these spaces that deliberative citizens can most effectively maintain the balance of procedures and pluralism.

So although there are many examples of educational practice along the lines I have suggested, e.g. those that use Socratic methods to nurture the autonomy, creativity and sociability of children, these practices are currently trapped in an economic context where 'education for productivism' is the overwhelming priority. Hopefully, this chapter supplies deliberative citizenship with a new context, one where discourse is at the centre of democracy rather than being subservient to market relations.

\section{A welfare democracy}

We therefore have two premises. First, that post-war welfare reforms assumed that the democratic revolution was over, such that social citizenship rights did not need to question the nature and operation of political citizenship. Second, that aggregative democracy has gone as far as it can go, leading to the atrophy of democratic institutions and practices that do not connect with the discursive noise of civil society. If we now put these premises side by side, we begin to suspect that repairing the welfare state's democratic deficit requires far more than the introduction of more democracy into social policies, e.g. elections, consultation exercises, constitutions, welcome as these would be. Instead, a different type of democracy is required, one in which the producers and consumers of welfare services move as close together as is feasibly possible, and procedural mechanisms such as elections express the democratic conversation rather than substituting for it. In short, a 'welfare democracy' would be the institutional equivalent of deliberative democracy (Ellison, 1999), an extension of discursiveness to welfare systems without which the deliberative project is likely to stall. I have already given some indication of what this might imply for education. The big question is, how might be begin to engineer a welfare democracy? To answer this question, we have to be aware of the main obstacle that lies in our path. 
Essentially, a welfare democracy would need to challenge the hegemony of conservatism. Why? Because a substantive democracy requires a greater degree of social equality than over two decades years of free market capitalism has been able (or willing) to create (Gutmann and Thompson, 1996). ${ }^{7}$ Without social equality, some voices are inevitably more powerful than others, able to access and mobilise resources faster and more effectively than the relatively powerless - this does not mean they are the poorest communicators (Dryzek, 2000: 172), merely the most disadvantaged ones. So, although capitalist markets may be able to live with massive inequalities (and, of course, to require them), democracy breaks down beyond a certain point. Indeed, democracy has suffered most in those countries which have applied a free-market logic with the greatest fervour, with knock-on effects for civil liberties and the quality of public life. Therefore, since laissez-faire capitalism undermines crucial aspects of democracy (Dahl, 1985; Bowles and Gintis, 1986), and hinders the further democratisation of society, then any attempt to democratise welfare systems that is not based upon social equality would barely empower the disempowered, no matter what constitutional safeguards were in place (Ellison, 1999: 78). ${ }^{8}$

So, the obstacle that lies in the path of a welfare democracy is both political (how to discredit conservatism in a manner that the NSD has failed to achieve) and intellectual (how to ensure that deliberative democracy and social equality conjoin at the theoretical level). Let us take the intellectual component first, for if we can work this out, then we may be able to build the resources needed for a political challenge. Three dimensions of social equality can be identified as essential in this respect.

First, the equalisation of material resources is important, for the reasons just stated. Evidence suggests that some welfare states can redistribute income fairly successfully (Goodin et al., 1999) but that the redistribution of other resources, such as capital, has rarely been on the political agenda. The democratic deficit of state collectivism could be partly attributed to this reluctance to address the property relations that underpin welfare capitalism, for it is in reconfiguring these relations that political control of the economy is ultimately ensured, rather than in applying measures such as Keynesianism and nationalisation, neither of which engenders the required decentralisation of power. Democratisation therefore requires some kind of socialised property system as its condition (Krouse and McPherson, 1988) - see Chapter 7 and again below.

Second, welfare democracy requires the equalisation of care, a gender equality which ensures that the public sphere is dominated neither by men nor by those who represent the interests of employees and employers. This means transcending the distinctions between producers and recipients, independence and dependence (White, 2000: 164). As we have 
seen in a number of previous chapters, these distinctions facilitate an institutionalised paternalism that gives priority to wage earning and undermines the status of 'the dependant'. Traditionalists will object that there are essential needs that some (especially children) will always be unable to provide for themselves. Yet the objection is not to paternalism, but to the institutionalisation of paternalism around an axis of needs-experts and non-experts. This is why, in advocating her universal caregiver model, Fraser $(1989,1997)$ demands room for oppositional vocabularies that can challenge expertise, on the grounds that needs do not exist in themselves, but are always located in a discursive context. A welfare democracy would seem to require the equalisation of vocabularies such that many of the 'cared-for', including children, can enter into the means of their care as discursive and often as equal participants. Such has been the aim of the disability movement for many years now.

Finally, and as already indicated, an equalisation of time is also important (Gorz, 1999; Beck, 2000; Fitzpatrick, 2003b). If western societies (especially conservative ones) currently suffer from 'time poverty', i.e. overwork and stress, and if this is related to social inequality, where relatively few achieve a desirable balance between employment and nonemployment time, due to the imperatives of a 'free' labour market, then both the motivation and the goal of deliberative competence are one and the same: the freeing up of social time (cf. Gershuny, 2000). I have suggested that more time is crucial if time is to be meaningful and that only deliberative citizens are fully equipped to render such meaning. A welfare democracy therefore requires much more than those who have only been trained for earning and shopping, it needs the communicative participation of 'time-rich' discursive actors across a range of deliberative domains.

So the number of social forms that are compatible with a welfare democracy are not infinite and are biased towards institutional reforms that correct the imbalance of resources, care and time that presently lie at the heart of social injustice. This is why a welfare democracy is not compatible with free-market capitalism.

At this point, critics will allege that there is a contradiction to my argument. For if democracy implies pluralism (see the discussion above and in Chapter 1), then how is it possible to exclude from a deliberative welfare democracy the discourses of conservatism? I should first point out that the intention is not to exclude conservatism from the discursive conversation, partly because aspects of conservatism may be true (even if we reject the whole), partly because conservatism may be help to 'disclose' society (see Chapter 1) whenever Left principles ossify into dogma, as happened in the Soviet Union for instance, and partly because that conversation is necessary if conservatism is to be challenged and disentangled from the egalitarian politics of social democracy. However, if 
a welfare democracy implies egalitarianism, then it would have to both accommodate and marginalise those whose political philosophy is nonegalitarian. ${ }^{9}$ Although democracy requires basic procedures upon which all participants can agree, these procedures will always be subject to subtle but important revisions, due to the very contestation over the desired outcome which is the lifeblood of democratic interaction. So although deliberative democracy's emphasis is upon procedure - in contrast to, for instance, epistemic democracy's emphasis upon 'correct answers' (Estlund, 2002) or republicanism's emphasis upon public reason (Pettit, 2001) - there is no such thing as pure proceduralism; procedures are themselves subject to democratic contestation. So I am not advocating that conservative parties and groups be deprived of rights and opportunities, but certainly greater action is needed than hitherto against that which has unduly skewed the influence over social and economic agendas in a conservative direction, e.g. political donations and lobbying, media bias and cross-media ownership, business monopolies, corporate influence, public-sector managerialism. Chapter 1 made the point that, whereas pluralism is valuable, what ultimately drives pluralism is a battle between those wish to steer liberal democracy in the direction of their favoured principles and values.

But if this criticism falls, then have we surmounted the intellectual obstacle mentioned a sort while ago, i.e. the need to show how and why deliberative democracy and social equality conjoin? Not quite. For what we have done is indicate why democratisation requires the equalisation of resources, care and time; what we have not done is to explore the converse: why equality requires democracy. The problem is that social egalitarianism has been under sustained attack since the 1970s, despite occasional victories, despite the examples of the Nordic welfare states and despite what electorates tell pollsters and social scientists. This attack has been driven by conservatism, but may ultimately be attributed to the bureaucratic, rigid and uncreative equality that welfare states created and which still seems deficient compared to the dynamic freedoms market capitalism allegedly creates. We face a paradox, then. If democratisation requires greater social equality, then social equality cannot be created without democratisation. For in order to create social equality, people must first be persuaded of its merits, yet they cannot be persuaded without the kind of deliberation of which social equality is a necessary condition. If we could transport ourselves to an 'original position' then the paradox might not arise. Unfortunately, in the real world we are faced with the problem of transition, and the kind of cooperative activity and interactive reflection envisaged by Rawls has to emerge from within capitalist societies where egalitarian politics continue to lack much support. Therefore, distinguishing between the political and intellectual compo- 
nents of the obstacle in the way of a welfare democracy only gets us to far. In truth, we cannot discuss theory without giving some thought to strategy and so to the actors who are to advance that strategy.

Given the fact that ecowelfare draws upon a variety of egalitarian, feminist and environmental ideas, this suggests that our analysis should centre upon social movements and their ability to counter the conservative hegemony and to radicalise social democracy. Before proceeding, two points need to be made. First, I will not delve into the details of social movement theories, namely how, why and under which circumstances social movements emerge and mobilise. This will divert us too far from our main task, which is to examine whether a welfare democracy could reconcile the principles of attention and distributive justice. Second, I will assume that the distinction between old and new social movements is unhelpful, overemphasising discontinuities and putting in question the relevance of a class analysis. Again, there is no time to go into detail, but I will be assuming that, in the developed societies, social movements operate against the background of societies that have to be described primarily as capitalist (rather than patriarchal, colonialist, homophobic, etc., even if all of these things), albeit societies that crack along a number of discursive fractures. This means - and here we anticipate our conclusion - that we can never create economic equality without addressing forms of discrimination and injustice that are more specific to gender, ethnicity, etc., nor can we create gender equality, ethnic equality etc., without tackling economic inequalities. In other words, a social movement can only be fully understood in its relationship to others within a hegemonic/counter-hegemonic field that is to be understood in terms of the inequalities that free market capitalism can moderate, but either cannot or will not eliminate.

\section{Social movements and the prospects for democracy}

The history of ideas is littered with attempts to derive moral norms from ontological foundations that always crumbled when they were examined in retrospect. And with the destruction of those foundations so the moral superstructure topples over, leaving philosophers to salvage whatever they can from the ruins and try again. It was impatience with this endeavour which led many in the twentieth century to design philosophies that could float free of foundations and essences and so remain immune from disintegration. Wittgenstein and Foucault were only ever the godchildren of Nietzsche. This impatience was validated by the final discrediting of Marxism and so began a series of the long marches towards reconciliation with 'the real' (allowing capitalism immunity from the forensic 
analyses that discredited Marxism), towards a desire to play among the ruins rather than reconstruct them into grand narratives, and towards high theories that do not have to get their political hands dirty. Critical theorists have found themselves pushed and pulled between these three convoys, raiding from each what they might need to restart a new procession of their own. The attempt has been to devise moral (and so political) norms, without loading them with too many ontological assumptions. This has been the project of Habermas, to mention one among many others, in his search for a communicative rationality that could be spoken by the post-metaphysical self.

Why is this story relevant to social movements? Because if social movements do represent an alternative to conservative capitalism, then how we think of them and how they think of themselves makes a difference. A social movement that interprets itself as 'playing among the fragments' offers an alternative potential to that which sees itself as progressive in the traditional sense. As indicated, we are not going to run through each and every aspect of social movement theory, but there is one question we cannot avoid: do social movements carry within them the potential for universal emancipation?

Those who have questioned the aim of universal emancipation have gone under a number of different names but 'radical democrats' seems most appropriate in this context (Laclau and Mouffe, 1985; Laclau, 1996; Mouffe, 2000). For radical democrats, power (as both production and repression) is inescapable and so social movements relate to one another through discordant lines of friend/enemy antagonisms and discursive conflict over meaning and identity. Indeed, social movements are themselves only transitory and conflictual formations. Everything is infused with democratisation, and deliberation always refers back to the context of the deliberators, since we have no recourse to an extra-contextual frame of reference; democracy is always entwined within relations of power. The trick is to ensure that enemies are 'democratic enemies' in that they do battle upon a space that both agree to maintain. This space, though, is not a universal ground, for universalism is not a pre-existing source of identity and rationality, but a constructed denominator that surfaces occasionally through a contingent, hegemonic alliance of particularisms (Butler et al., 2000). Because the subject is never complete, closed or identical to itself, then this makes democracy an ineluctable part of identity and association. Democratic consensus, then, is always open-ended and disputable. In short, radical democrats do not reject universalism per se, merely those principles that are presented as final, universal truths exempt from contestation. Social movements and democracy are therefore emancipatory but this is not a universal emancipation, if by universalism we mean 'true for all people at all times'. 
A longer critique of radical democracy is given in Fitzpatrick (2002b), but here all we need point out is that radical democracy is somewhat parasitic upon the critical theories that it eschews. They represent radical democracy as incommensurable with the kind of universal rationality theorised by Habermas and yet also insist that a democracy cannot survive without a 'plurality of competing forces' (Mouffe, 1999: 51). Does this mean that they are recommending we reject Habermas's ideas or not? If so, then does this not contradict their support for democratic plurality? If not, then what status in a radically democratic society would those ideas possess? Presumably, we cannot say that universal rationality has some persuasiveness after all, since this fundamentally contradicts the philosophy of radical democracy. Or is it that the idea of universal rationality should be considered both objectionable, but also necessary for the maintenance of democratic plurality, the equivalent of stating 'I disagree with what you say, but defend your right to say it'? But whereas this is normally taken to imply that even ideas you believe to be wrong may contain some grain of truth (on the lines established by Mill (1989)) radical democrats cannot make such an appeal, given the contrast they set up between a universalism that is a hegemonic construction (radical democracy) and a universalism that is true for all people at all times (critical theory).

In short, radical democracy speaks the language of pluralism, but without reference to an extra-discursive realm, debates and disagreements about the nature of which is precisely what gives democracy both its plurality and its meaning. By treating everything as contextual, radical democrats leave democracy hollow and without intellectual force. This does not mean that universal rationality determines the content of democracy, because the extra-contextual realm can never be fully transparent to us, but it does imply that some universals, true for all people at all times, can be discovered.

It therefore follows that to spy a potential for universal emancipation within social movements and within democracy properly conceived is not as difficult as those such as radical democrats imagine. What might the basis of that potential be? Let me state bluntly that it consists first and foremost in opposition to oppression, for oppression stifles the ability to articulate claims and so enter into democratic discourse in the first place. The exact nature and circumstances of oppression (and therefore of antioppressive strategies) are certainly contestable. In South Africa prior to 1990, for example, the anti-Apartheid movement had to articulate the linkages between the economic and racial dimensions of oppression, and then rearticulate as transformation of its own identity once Apartheid fell. But what is not contestable, what is a universal and not merely a hegemonic truth, is that democracy is only ever incomplete in the presence of oppressive relations. Democracy must therefore aim itself towards the 
creation of non-oppressive social relations, and so the democratic project requires the reconfiguration of actually existing democracies. How? Through social movements committed to non-oppression and therefore to the democratisation and equalisation of power. ${ }^{10}$

But what this universal potential does not imply is the idea either that each social movement must universalise its aims, i.e. attend to all forms of inequality and oppression, or that social movements should formally unite under one heading, the equivalent of Marx's world historical class. Radical democrats are correct to resist such suggestions. However, what social movements must do is make connections between struggles and carry those connections around with them, i.e. be ready to challenge other forms of oppression when they impact upon their more direct concerns. For example, this means that although trade unions will be mainly concerned with workplace relation, this should not exclude from their purview other relations that affect the workplace, even when these do not appear to be directly connected, e,g, domestic violence. Similarly, women's groups will be mainly concerned with issues of distributive and cultural justice that pertain to women, but will also recognise other matters that relate to reproductive value, e.g. the health implications for their children of an unsustainable environment.

(Before I am accused of stating the obvious, let me acknowledge here that I am fully aware of the extent to which social movements already practice this kind of 'grounded universalism'. They are often much smarter than the social theorists who deign to lecture at them, and Walby (2001) is correct to underline why it is the theorists who must catch up with the practitioners rather than the other way around! Nevertheless, what social theory can do is provide practice with an historical and conceptual context, and I will indicate why this is important in a moment.)

In short, the universal potential of social movements lies in creative yet never complete reconciliations that they achieve between the principles of distributive justice and attention (see Chapter 6). To protest and struggle against oppression is to demand a form of equality that even several hundred years of progress has still not achieved. But struggling against one form of oppression is redundant without the recognition that oppression is a relation, a web of dominative power, requiring the additional recognition of one's position in a network of counter-oppression. It is to care for all forms of oppression, including those that are not one's immediate business, to acknowledge the presence of everyone in the network, even though alliances will bring some closer than others. The first reason why social theory is important is because social movements sometimes get it wrong. Eyes fixed on the proximity, they can forget to take stock of the wider battle; understandably focused upon one form of domination, 
they sometimes imagine that it can be corrected through a new oppression rather than by dispelling the dominative impulse. Social theory can remind us that domination is not the solution to itself. To put it simply then, oppression is organic and, just as there is little point in healing only one part of an ailing body, so there is little point in resisting one form of domination to the exclusion of others. The potential of social movements is therefore for an organic universalism, a potential that they often realise but sometimes do not.

What this suggests in turn is that we must be able to read the traces of the disease that we are trying to cure. The interplay of distributive and attentive concerns does not occur naturally; it requires the identification of common enemies, the principal obstacles blocking the paths of emancipation. In short, agency is meaningless without a strategy and there can be no strategy without something to resist. Organic universalism implies not only a network of movements, but strategic orientation towards a common goal. So we have another balancing act to perform. Counteroppression implies the coordination of the non-coordinable: too much coordination and social movements collapse into each other; too little and they fly apart and fail to recognise themselves within each other. The second reason why social theory is justified, therefore, is as a means of balancing forces whose value lies in their tendency to resist balance. What this boils down to is the observation that social movements require deliberative democracy as much as deliberative democracy requires them, for, without the former, the noise of civil society is muted and without the latter, the noise may never fully connect with the democratic process.

And if deliberative democracy refers both to welfare democracy and to social movements, it follows that social movements are also vital to the democratisation of welfare. In other words, the paradox which I sketched earlier (concerning democratisation and social equality and the idea that each is the condition for the other) is potentially resolved through forms of collective action and political mobilisation that aim to reform social policies and welfare systems in such a way that equality is democratised and democracy is made more egalitarian. If the link between democracy and equality was noted two centuries ago by Tocqueville (1990), and if liberal democracy is not necessarily the final stage of the democratic revolution, then a more thorough convergence of the two principles is called for and state welfare may be the most effective instrument currently available to us if this 'democratic equality' (Levine, 1998: Ch 5) is to be achieved. How? By social movements paying more attention to welfare issues and egalitarian parties, policy-makers and political groups taking greater account of social movements. If social movements really do represent the ever-partial reconciliation of distributive justice and attention, 
then the mutual learning of social movements and social policy can only strengthen these principles and offer a counter-hegemonisation to the inequalities and cultural myopias of conservatism. We therefore have prima facie reason to believe that a welfare democracy could reconcile the principles of attention and distributive justice.

But what might this 'democratic welfare equality' actually look like?

\section{The convergence of association and deliberation}

As before, I do not want to be accused of reinventing the wheel and I am aware of the extent to which social movements - the labour and women's movements particularly - have successfully influenced the development of social policy. Indeed, it could be said that social democracy has flourished most where it has relied as much upon social movements as upon politicians and bureaucrats (Moschonas, 2002: 156-8). Where this has not been the case (in the UK for instance), where they have been less firmly rooted in the lifeworld, then conservatives have found it easier to detach social democratic institutions from those they were originally designed to assist. What has changed is the context. The free market capitalism of the late twentieth and early twenty-first centuries is a response to this very interaction of social democracy parties and social movements that was itself a reaction to the laissez-faire liberalism of nineteenth- and early twentieth-century capitalism.

Therefore, social democracy and social movements have to relearn one another. The former has to hear the new noises that are coming from below, the latter has to speak to those who fight for equality in other forums - rather than condemning all parties and politicians as just the same'. ${ }^{11}$ As Maschonas (2002: 236) observes, social democrats have been adept at following the trends and formations of social movements but much less skilful at anticipating and shaping them. And although it is true that social movements lack the grounded solidarity of the industrial working class (Moschonas, 2002: 256) - the traditional source of social democracy's strength - this only reinforces the need for social democrats to construct new collective identities, rather than trying to discover solidarities that it can then comfortably 'borrow'. In short, social democracy has to remobilise itself from within the fissures of civil society, to abandon the passivities of its golden age (when it could recline upon working-class support) and the conservatisms of the NSD (an endless adaptation to the existing mainstream), to rediscover the energy of the nineteenth century, when social democracy was as much the labour movement's normative antecedent as its political consequent. Therefore, I am arguing not for the abandonment of class politics, but rather for its renewal within a politics 
of social movements, not the pursuit of single-issue causes that can be spliced uneasily together, but the articulation of diverse solidarities around key principles (distributive justice, attention, sustainability), not the rejection of middle-class 'insecurities of affluence', but their renarration in terms of an egalitarian ethic.

This is what I meant earlier when I mentioned the need for a more creative interface between parliamentary and non-parliamentary forms of politics. The disconnection (the deafness of formal systems to the discursive conversations taking place around them) from which developed, aggregative democracies currently suffer cannot be set right by cutting the parliamentary and the non-parliamentary sectors adrift. This is the dream of many within both elite and non-elite organisations. For the former, democratic consultation can be limited to focus groups, newspaper letter pages, stage-managed rallies and media events; for the latter, the new politics bears no resemblance to the old and so consists of gesture, symbolism and violence for the sake of violence. Perversely, the spin doctors and the rejectionists both use the very same argument in order to despise the other: government is for insiders only. Fortunately, most citizens have not stopped talking to government just because the governing classes are reluctant to listen.

However, it is not my task to sketch what this more creative interface between the parliamentary and non-parliamentary might resemble as a whole. Instead, I want to say something about it with specific reference to welfare democracy. The point of a welfare democracy would be to empower and so help to reverse the experiences and feelings of powerlessness that are creating the pathologies of contemporary society. For, when people do not feel in control of their lives, they tend to reach for scapegoats and simplistic solutions; extremism and fanaticism do empower, if only in a destructive way. Yet the new extremism (ethnic nationalism, religious fundamentalism, xenophobia) represents less the unravelling of the mainstream as its negative image. By being unwilling to carry the democratic revolution forward, by facilitating economic and social forces that wash away the fixed grounds needed for ontological security, by crowding into the Centre and favouring an elitist, gridlocked politics, the new spaces of extremism have been opened by a mainstream betraying its own legacy.

Yet it is not as if the mainstream has been unaware of the dangers that it has engendered. It would not be inaccurate to characterise social democracy during the post-communist era as the search for a reconciliation between deregulated capitalism and a civic rootedness that would re-socialise global forces. This explains why a number of 'big ideas' have proliferated. 'Stakeholding' was a big idea that ultimately foundered on the disagreement between those who saw it as an alternative to deregu- 
lated capitalism (Hutton, 1995, 2002) and those for whom it meant limited inclusion against a background of inequality (Blair, 1998). 'Stakeholder welfare' has therefore come to possess little meaning, other than the attempt to lever poor households into the private welfare market. 'Social capital', too, has enthused the policy wonks, tying in nicely with the fashionable emphasis upon employment and community. The very title gives the game away, sadly. For rather than suggest a new form of economics, much of the literature of social capital has been designed to shore up the spaces of stability, the informal networks and the civic trust that postKeynesian economies can only undermine (Fukayama, 1996): it is a bandage for the wounds of global capitalism. And EU integration holds to the ideal of a social Europe that will accommodate citizens and not just market actors. Yet this ideal is constantly impaired by a confusion of 'citizen' with 'worker' and by the EU's tendency to follow the liberalising agenda of the IMF, World Bank and WTO.

The social democratic mainstream has therefore pinned itself to a contradiction: it has committed itself not to a globally regulated capitalism, but to a reregulation of the social spaces that laissez-faire economies constantly destabilise. This contradiction is more in evidence where the NSD has taken hold (see Chapter 3) but could be said to describe the contemporary dilemma of social democracy per se. However, this period has also seen new ideas emerge from within the academy that could help to renew social democracy. Take the debate concerning 'associative democracy' for instance (Cohen and Rogers, 1995; Carter, 2002).

The aim of associative democracy would be to create new forms of collective and communal forms of association that would mediate between state and civil society, without allowing either the state to become too big (so dirigisme would be avoided) or imposing a unitary identity upon civil society, i.e. the way in which communitarians overcompensate for the fragmentations of market economics. Associative democracy is therefore something of a middle way between state socialism and market capitalism, but one that, unlike the Third Way, does not remain complacent about the social detritus that the market revolution has left in its wake. Its purpose is to re-empower by bringing the spaces of economic and social production and consumption as close together as feasibly possible. It could represent a more creative interface between the parliamentary and the non-parliamentary by not confusing the former with state collectivism or the latter with market individualism; associative democracy would try to democratise each by democratising both.

Although associative democracy therefore bears implications across the economic, political and social spheres, I want to take a particular look at the work of Paul Hirst, since it is Hirst who has come closest to applying these ideas to social policy (Fitzpatrick, 2002a). Hirst (1994, 1997, 1998) 
argues that large parts of government can and should be devolved to selfgoverning, voluntary, publicly-funded and publicly-accountable associations, whose members would have varying degrees of control over public systems of provision. An associational welfare system would maintain an emphasis upon distributive justice, but would be less collectivist than the classic welfare state. Self-governing associations would deliver and/or purchase many of the services that are currently provided either by the state or the market, yet play a more systematic role in the welfare of society than the traditional independent sector. Hirst envisages that we would all become members of these associations, with rights to vote and to exit if we choose, and that the associations will have to meet certain criteria if they are to receive public funds via some form of formulafunded voucher system.

The attraction of associational welfare is that it would empower the users of public services more effectively than either state collectivism or a Third Way approach. Those who defend the former (Stears, 1999) tend to overestimate the paternalistic virtues of the welfare state and to underestimate the extent to which any inability that citizens now possess to take greater control of their lives is a regrettable effect of paternalism, rather than a justification of yet more paternalism (cf. Hirst, 1999a). Those who defend the latter overemphasise both the importance of globalisation and the declining validity of older versions of social democracy (Hirst and Thompson, 1996; Hirst, 1999b).

However, there are three main problems with Hirst's formulation of associative welfare (cf. Carter, 2002). First, he places too much stress upon exit and not enough upon voice. His associations would be representative democracies in which the main constraint upon associations' leaders would be the withdrawal of their members and the consequent loss of public funds (Hirst, 2000: 289). This fails to break away from today's consumerist ethos, where voice is only ever an individualistic prelude to exit rather than a cooperativist strategy. This is not to argue that a welfare democracy would have to limit the right of exit; instead, it is to recognise that it is the market system which limits the right of exit whenever public goods are concerned. Therefore, the point is to regard voice and exit as compatible, if they are both conceived in cooperativist and mutualist terms. It is here that social movements could be particularly relevant, since if they were to embody the organic universalism mentioned above, then social movements would need to disperse themselves across associations (rather than congregate upon particular associations as a form of single-issue politics) in order to promote the aims of democracy and social equality. Social movements would encourage the voices of associative deliberation. 
The second problem, then, is that whereas he once regarded it as a means of renewing socialism, Hirst came to present associative democracy as politically neutral. This is similar to Offe's (2000) mistake in imagining that working out the proper civic mix between state, market and community can be done without reference to ideological schemes. What this ignores is the fact that any associational welfare worthy of the name would have to be egalitarian (otherwise the practices of exit and voice would do no more than mirror existing patterns of inequality) and so subject the current meanings of 'state', 'market' and 'community' to challenge, challenges that could not occur without ideological orientations. As I argued above with reference to deliberative democracy, this need not mean that a welfare democracy would exclude non-egalitarians from the conversation, but it would have to directly confront and present alternatives to the conservative hegemony. The classic welfare state shifted the political battleground to the Left and associational welfare would have to possess a similar goal.

The final problem is that Hirst does not pay enough attention to the centralised state, insisting that the methods of governance would flow from the state to associations. Yet here, again, we are presented with an either/or logic which treats the state and associations in exclusivist terms. Any shifts in the loci of governance must aim to enhance the democratisation of the state, rather than merely sublimating democratic governance to the civic sphere. It may be that Hirst confuses collective ownership with state ownership, such that if the latter is no longer credible, then the former has to be abandoned also. What remains underexplored, then, is the extent to which an associative democracy could facilitate economic democracy along the lines sketched in Chapter 7. Some associations could control socialised firms and funds, channelling the investment strategies of their members towards socially and environmentally desirable goals. But if this were to be the case, then some state action would be needed to regulate this system, as well as helping to maintain parity between associations, and a considerable amount of state action would be needed at the regional and global levels to bring about the socialisation of productive assets. This is obviously a daunting and long-term task, but Hirst (among others) does the debate no favours by ignoring it.

In short, although Hirst's associational system approximates to what a welfare democracy might look like, the latter would have to give far greater emphasis to voice, it would need to draw upon egalitarian conceptions of cooperative mutualism and it would need to reconstitute the welfare state around an egalitarian politics (of socialised ownership), rather than merely devolving it to voluntary associations. It is possible to envisage welfare associations (Fitzpatrick, 1999c) - mutuals, cooperatives 
and not-for-profit social enterprises - acting as the conduits for such reforms. Without these kind of revisions to the basic blueprint, then were it ever translated into the political reality, associative democracy would risk the same fate as befell stakeholding, i.e. of shoring up a conservative system. Unless association and deliberation converge around an egalitarian social democracy then associative democracy may fail to hear the democratic noise and deliberative democracy may lack an institutional form that transcends experiments with citizens' juries and policy panels. Similarly, unless social democracy rediscovers itself at the interface of state and civil society, then its traditional rationale may continue to lose its hold on the social imagination: how to collectively control a market economy without giving too much power to a state that would allow civil society to wither.

Empowerment therefore requires both association, deliberation and equality, and so a welfare democracy would need to be founded upon both new forms of governance (procedure) and discursiveness (pluralism). And ultimately, the creative interface of parliamentary and nonparliamentary politics requires that social democrats and social movements begin to learn from one another more effectively than has been the case during the detour towards the NSD. This leads us back to the problem mentioned earlier, the problem of transition and how to translate these ideas into political reality. With parties traditionally seeking to institutionalise social movements and movements both welcoming and resisting such institutionalisation, then what can be done to encourage the more creative learning processes that I have presented as vital to deliberative democracy? There is no easy answer to this and I return to it in the concluding chapter. For now, let me make the simple point that so far as deliberative democracy is concerned, we do not talk about it and then create it, we begin to create it by talking about it. The problem of transition is a problem for those who recognise the need for transition; and if both egalitarian social democrats and non-oppressive social movements recognise that need and each other's recognition, then the problem of transition may lie as much behind us as before us.

\section{Conclusion}

We began with a post-universalist account of social citizenship and the view that social rights had become discredited because they were detached from the need to advance the democratic project further. We then contrasted aggregative democracy and deliberative democracy to see what this advance might resemble and I noted that a reconciliation of 'procedure' and 'pluralism' is of key importance. I then sketched a theoreti- 
cal outline of a welfare democracy and characterised it as an egalitarian alternative to conservatism. However, this alternative cannot be imagined without reference to questions of actors and strategies, suggesting that the universal potential of non-oppressive social movements should make common cause with social democratic parties, despite the fact that many within those parties have fallen under the conservative sway. We concluded by exploring associative democratic ideas and I suggested that association and deliberation are both essential components of an egalitarian politics.

This brings our analysis of the ecowelfare triangle to a close. In Chapter 6 , I observed that its main principles should not be collapsed under a single heading, since it is facile to imagine that they always and everywhere cohere. Instead, ecowelfare ought to be regarded as diverse set of ideas that nevertheless revolve around the same set of objectives: to renew social democracy and turn it away from the NSD. The last three chapters give some illustration of just some of the theoretical debates with which this post-productivist social democracy might engage. And as I stated in Chapter 6, whether you agree with most, some or little of what I have said is not important, what is crucial is that you recognise there is something important to be disagreed with. If that is the case, then alternatives to the NSD have already been sighted.

\section{Notes}

1 For a longer account of the following argument, see Fitzpatrick (2002b).

2 Though the 'shallowness' of those roots differs from country to country; see Chapter 4.

3 These stages apply most directly to the UK but could, with some effort, be applied to other developed nations.

4 I should here add that I have also discussed the links between environmentalism and democracy elsewhere (Fitzpatrick, 2002d) and so suspect that democratisation is a means of linking together the ecowelfare triangle's three principles with greater coherence than is being suggested in Part II. However, not having worked out the full implications of this, I do not want to spend time on ill-formed speculations, nor do I wish to suggest that deliberative democracy is a panacea (see below). Therefore, all I can do here is to indicate a direction for future work.

5 I will not be offering a systematic critique of deliberative democracy and believe that it should not be seen as a panacea for the ills of western democracy. In particular, deliberative democracy can be accused of neglecting nonrationalistic forms of voice, of underemphasising the inequalities of voice, of not always specifying the necessary limits to democratic debate and of failing to get to grips with the problem of social scale, i.e. how can small-scale delib- 
erative fora provide large, complex societies with the legitimacy they require? These issues are discussed in Dryzek $(2000,2001)$, Young $(2000,2001)$, Weeks (2000) and Thompson \& Hoggett (2001).

6 For reasons of limited space, I will leave to one side another important sphere, which is that of the media and ICTs. However, I acknowledge that these are absolutely crucial to future of democracy and are relevant to the discursive education that I am about to defend.

7 In contrast to her earlier work, Young (2000: 92-9, 105) now makes room for the importance of economic structures and inequalities that are not reducible to the cultural (see Chapter 6). However, she has yet to grapple with the difficult implications this bears for deliberative democracy.

8 However, I leave open the question of how much equality is required. I will simply be assuming that the post-1970s lurch towards greater inequality must be reversed and so the economic philosophy of conservatism finally overturned. However, I suspect that unless we revisit an issue that I am about to mention (concerning property relations) then any inroads into social inequalities will be modest and short-lived.

9 And remember that such decisions are inescapable within any liberal and democratic society, including unequal ones; how does a society live with those who would undermine it?

10 Note, then, that I am not claiming that all social movements are nonoppressive. Obviously, this is not the case. Instead, I am deploying the universal truth of non-oppressiveness to distinguish between those social movements which are progressive and those which are not. It is the former who might constitute the basis of an deliberative politics.

11 In this respect, the experience of environmentalism is salutary. Green movements and parties have undoubtedly constituted a welcome addition to politics and yet the intellectual gulf between Greens and social democrats remains largely wide and uninspiring, caught in the same old pincer movement between realists and idealists. 